\title{
Article
}

\section{'The Foul Conspiracy to Screen Salisbury and Sacrifice Morton': A Microhistory of Extortion, Resistance and Same-Sex Intimacy in Early Nineteenth-Century London}

Orr, David

Available at http://clok.uclan.ac.uk/18019/

Orr, David ORCID: 0000-0001-6128-8296 (2018) 'The Foul Conspiracy to Screen Salisbury and Sacrifice Morton': A Microhistory of Extortion, Resistance and Same-Sex Intimacy in Early Nineteenth-Century London. Journal of Social History, 103 (357). pp. 571-587. ISSN 0022-4529

It is advisable to refer to the publisher's version if you intend to cite from the work. http://dx.doi.org/10.1111/1468-229x.12625

For more information about UCLan's research in this area go to http://www.uclan.ac.uk/researchgroups/ and search for < name of research Group>.

For information about Research generally at UCLan please go to http://www.uclan.ac.uk/research/

All outputs in CLoK are protected by Intellectual Property Rights law, including Copyright law. Copyright, IPR and Moral Rights for the works on this site are retained by the individual authors and/or other copyright owners. Terms and conditions for use of this material are defined in the policies page. 


\section{Introduction ${ }^{1}$}

On the $6^{\text {th }}$ December 1827 , Richard Anthony Salisbury prosecuted John Morton for attempting to extort $£ 50$. Salisbury was a botanist of minor importance, well connected and a fellow of the Royal Society. In 1802, after recovering from financial collapse and a failed marriage, he was sufficiently solvent to purchase 18 Queen Street, Edgware Road. Here Salisbury lived alone, but for his servants, until his death in $1829^{2}$. During the spring of 1827 , Salisbury had begun shopping for plants at Jenkins's nursery, near Queen Street. Here he met and befriended John Morton, a twenty-five year-old labourer, who had recently emigrated from Dublin with his wife $^{3}$. By July 1827, Salisbury was confident enough of Morton's character to offer him the job of live-in manservant at Queen Street. Morton accepted, but five months later both men were at the Old Bailey defending themselves against competing accusations of attempted extortion and sodomy. The trial concluded with Morton receiving seven years transportation for attempted extortion, but only after the jury condemned the character of the prosecutor ${ }^{4}$. What followed was a lengthy appeal by the standards of the time. Amidst the claims and counter-claims, petitions and letters, Joseph Lancaster, Morton's advocate, alleged a criminal gang had provided false witnesses and evidence to help Salisbury win his case. In the end Morton's sentence stood, but not before a world normally hidden was laid bare before the public gaze. The following microhistory will investigate the trial and appeal, and competing explanations of those involved in the Morton versus Salisbury case.

Upchurch correctly notes that there was frequent newspapers coverage of sex between men from the $1820 \mathrm{~s} \mathrm{on}^{5}$. Yet, there are relatively few detailed historical records of these cases. Legal records and journalistic articles manifested a conscious attempt to supress details of sex between men. Besides, the men themselves were 
keen to keep their sex lives private, partly because of increasing threats of exposure, extortion and legal sanction ${ }^{6}$. Consequently, contemporaries rarely heard from those accused of having sex with other men. When it did occur, discussion of 'unnatural crimes' was often couched in language that emphasised their heinousness ${ }^{7}$. Cocks rightly notes that secretive, indirect and nuanced forms of language developed later in the century to circumvent these prohibitions. However, the relative slenderness of both his evidence and discussion of sex between men in the early nineteenth-century further demonstrates the paucity of detailed historical records for the period ${ }^{8}$. The petitions, letters, affidavits and investigations relating to the Salisbury v Morton case offer a rare and detailed insight into the lived experiences of men accused of same sex intimacies in the $1820 \mathrm{~s}^{9}$. In the first instance, the article adds to the evidence and historiography in this area.

Age, class and privilege are also essential to a full understanding of this case $^{10}$. Clearly, Salisbury and Morton occupied different class locations. Morton was Salisbury's Servant. He was an Irish immigrant, with no skills and little to support his character. Morton was also considerably younger than Salisbury. For these reasons, Morton's evidence may have been easier for the jury to dismiss, given the difficulty of fully establishing his trustworthiness and character. The pioneering work of Weeks, Bray and Netta-Murray tended to downplay these other contexts of power. Later studies by Upchurch, Cocks and Trumbach have been more cognisant of privilege, reputation and class. Nonetheless, Upchurch's analysis tends too much toward class as an overarching and determining context. Trumbach's focus on reputational damage and class location ends up presenting sodomites as passive victims of contemporary convention $^{11}$. These structural explanations alone do not do justice to the complex intersectionality of power relations evident in the Morton $v$ Salisbury case. Power 
most visibly at the micro level is in reality neither singular nor fixed in its operation. Consequently, to view the case through the lens of either sexuality or class would constitute a failure to recognise the fluidity of power relations revealed by the case ${ }^{12}$.

Therefore, the following discussion of agency and micro power relations in Salisbury versus Morton, and other related cases, will also develop to the historiography in this area. This examination of Morton $v$ Salisbury will also add to the relatively small but growing number of case based micro-histories ${ }^{13}$. Here, individual experience and action offer a way of understanding the complex interaction between actors' choices and their understanding of contemporary (legal) narratives concerning sodomy and the sodomite. Likewise, the articulations of judges, juries and attorneys reveal heteronormative narratives that informed their decision-making in the case. Thus, the methodological approach adopted goes beyond a situation understanding of the Morton $v$ Salisbury case to reveal previously 'unobserved factors endemic' to the society in which Morton and Salisbury lived ${ }^{14}$

\section{Mutual Friends?}

Under most circumstances, a servant's attempt to extort money from his elderly and infirm employer would not elicit much sympathy. After all, John Morton was hired by Salisbury because 'he needed assistance, being 68 years old, and having recently experienced a fall that had resulted in a broken arm and a crushed hip ${ }^{15}$. Salisbury had also shown him exceptional kindness. Two days after Morton came to live at his Queen Street house, Salisbury 'made a present to Morton of a broach'16. During the next two months, 'Salisbury fed Morton whitebait and punch at Blackwell, and presented him with a gold ring', and on other occasions, according to Morton, made presents that included a silk waistcoat, a watch and a gold chain and seals. Salisbury 
also 'passed him off as his companion in the Duke of Dorset's garden, where they walked arm in arm, ${ }^{17}$.

It was not unusual for two men to walk 'arm in arm' as a sign of friendship or to aid an infirm employer. However, it was extraordinary that these two men presented themselves in public as social equals given that Morton was Salisbury's servant. And how are we to interpret the present giving? Did both men have a common understanding of why Morton was given these items? At the trial, Salisbury stated that, 'he bought these items because Morton did not have suitable apparel for his position, but this was not a gift ${ }^{\prime 18}$. However, the extravagance of the items belied Salisbury's explanation ${ }^{19}$. It is more likely that Morton needed to look the part if he were to pass off as Salisbury's companion, and that Salisbury had formed an attachment to Morton that went beyond their formal relationship. Indeed, Morton may have formed a similar attachment to Salisbury. Equally, he may have misunderstood Salisbury's intentions or accepted the items out of deference or greed. However, a more sinister motive was attributed to Morton at the trial, and in subsequent attempts to clear his name. Alongside a growing number of working class men in the 1820 s, Morton, it was claimed, had intended from the outset to extort money from the elderly and infirm Salisbury ${ }^{20}$. He was simply biding his time. According to Salisbury's cook, Morton accepted the position at Queen Street, knowing Salisbury had a previous indictment for 'attempting to commit an unnatural act'"21. This may have given him the idea for the extortion and the belief that Salisbury would readily pay rather than face exposure for a second time. This was certainly the view of Mr Harmer, the wellknown attorney, who refused to help Morton prosecute Salisbury as he 'considered Morton as having lent himself to Salisbury, for the purpose afterwards of extorting money from him ${ }^{22}$. 
Morton was well aware he could damage Salisbury's reputation by revealing the previous charge. In his deposition, Morton told the magistrate that Salisbury 'had been charged with a similar offence, and one gentleman present said he remembered the circumstances ${ }^{23}$. In his first petition, Morton stated that Salisbury's 'name and propensities are well known at the police office at the west end of town', and that he had been in custody 'some time ago upon a charge of indecent behaviour to a young man the name of Tomes, in Hyde Park' ${ }^{24}$.

With some justification, Morton felt that Salisbury's guilt would be confirmed by reference to this previous offence. Elite commentators and moral activists had been campaigning against sodomy and sodomites for more than a century before Morton's case came to court. During that time, Trumbach argued, sex between men was gradually reconstructed as separate from other (heterosexual) sexual practises. Men who engaged in those practises were cast as a separate and problematic minority alongside prostitutes, adulterers, forthright women, or anyone else who challenged new heterosexual constructions of family ${ }^{25}$. Nevertheless, criminal justice responses to sodomy and sodomites during the previous century were neither consistent nor particularly draconian by the standards of the time. As Netta Murray Goldsmith reports,

In the twenty years from 1731 twenty-two suspected sodomites appeared in the Old Bailey but none of those convicted was hanged. This pattern continued for the rest of the century, with executions of sodomites averaging less than one per decade ${ }^{26}$ 
After 1780, the number of capital convictions for sodomy increased. In the 1790s, the number of committals for sodomy also increased ${ }^{27}$. This coincided with the publication of Blackstone's Commentaries on the Laws of England and Gibbon's Decline and Fall of the Roman Empire, both of which contained virulently antisodomite viewpoints ${ }^{28}$. As Compton notes, this hostile environment also explains why Offences Against Oneself: Paederasty, Bentham's argument for the decriminalisation of consensual same-sex intimacy, was not published until almost a century and a half after the author's death ${ }^{29}$.

By 1810 , the number of committals for sodomy had risen to about eleven per year, with $29 \%$ of committals resulting in a guilty verdict ${ }^{30}$. Servicemen, particularly sailors returning from the French wars, were blamed for the perceived increase in sodomy ${ }^{31}$. The City of London authorities responded by locking the parks after dark to prevent sodomite activity, and it is now when the alleged assault on Tomes by Salisbury took place in Hyde Park. Although, Salisbury successfully sued his estranged wife for orchestrating the attack that gave rise to Tomes' allegation, he lost friends and reputation as a result of the incident ${ }^{32}$. That the incident resurfaced in Morton's deposition twenty-five years later to evidence Salisbury's dissolute character, also indicates lasting reputational damage.

Of course, press and public responses to the Vere Street prosecutions also suggests the development of dangerous and vitriolic attitudes towards sodomites at this time. On 10th July 1810, The Morning Chronicle had described the twenty-three men arrested as 'persons of a most detestable description', before stating that 'most of those who were discharged were very roughly handled; several of them were hunted about the neighbourhood, and with great difficulty escaped with their lives ${ }^{33}$. Their treatment involved 'being knocked down, kicked and covered with mud, despite being 
released because, 'the proofs against them [were] not sufficiently strong, ${ }^{34}$. Two months later, the seven men eventually convicted were attacked with 'fists, sticks and stones' as they made their way to the pillory ${ }^{35}$. The Times described the convicts as 'detestable wretches and monsters', and concluded its report with the following comment,

We exhort our legislators to take this subject into their most serious consideration in the ensuing Session. The monsters must be crushed, or the vengeance of Heaven will fall upon the land. Annihilation to such a detestable race can no otherwise be effected than by making every attempt of this abominable act punishable with instant death, without benefit of clergy ${ }^{36}$.

Salisbury's successful action against his wife in 1802 and Morton guilty verdict did not stop the jury in 1827 'strongly recommended mercy on account of the debased character exhibited by the prosecutor' ${ }^{37}$. Again, this indicates the resilience of the damage caused to Salisbury's reputation by the Tomes incident. It also suggests that attitudes towards sodomites were no more sympathetic in the 1820 s than at the start of the century ${ }^{38}$. In fact, Upchurch argues, bourgeois attitudes to same sex intimacy during this period were hardening. Hence, petitions for mercy, the "voice of the common people ${ }^{39}$, that reached their height in the 1820 s, also offer scant evidence of public resistance to the treatment of (alleged) sodomites. Between 1818 and 1832 , very few petitions were submitted on behalf of sodomites, and even they were rather half-hearted attempts to obtain a commutation. Typical are the cases of John Holland, William North and James Farthing. In the case of John Holland, only Edward Holland petitioned on his son's behalf, claiming that John was mentally 
deranged. Nevertheless, John Holland received no commutation of his death sentence $^{40}$. In William North's case, only professional (medical and legal) submissions were submitted, claiming that William was insane ${ }^{41}$. Both petitions exhibit early attempts to construct sodomy as a medical condition. In the case of James Farthing, only his mother petitioned on behalf of her son, simply requesting that enquiries be made into the case ${ }^{42}$.

Contrast this with the appeal and public response on behalf of John Wingfield of Greenhill, near Harrow, prosecuted for the brutal rape of Sarah Weatherby, a twelve-year-old girl, also from Greenhill. When arrested in 1827, Wingfield admitted his guilt to William Lipscomb, the arresting officer. He said to Lipscomb that, 'he knew he should hang for it', and asked the officer, to 'kill him on the road and not have any more bother ${ }^{43}$. Yet, in his affidavit, Wingfield stated that 'the girl was willing. I went up to the hedge and she followed me ${ }^{44}$. His petitions for pardon were supported by a number of Greenhill residents, under the guidance of their vicar JW Cunningham. They continued to deny Wingfield had raped Sarah, and cast aspersions upon Sarah's character and that of her family ${ }^{45}$. Meanwhile, Sarah was seriously ill, having haemorrhaged as a result of the attack. Wingfield hanged, but that is not the point. In his popular law primer, William Oldnall Russell had written that consensual sodomy between adults was a 'more heinous offence' than rape, a statement that seemed to capture the popular mood. Even here, where there was an identifiable victim, the victim was a child, and the appellant had confessed, there was broader and more concerted support for the appeal than that for any case of consensual sodomy involving adults prosecuted in London in the $1820 \mathrm{~s}^{46}$. Therefore, if sexuality was the only consideration, John Morton would have been optimistic that his appeal would succeed. 
It is unlikely that Richard Salisbury was oblivious to the increased antipathy towards and greater willingness to report alleged sodomites. His arrest for indecent behaviour in Hyde Park and the sustained perception of him as dissolute should have alerted Salisbury to the need for caution and secrecy. Yet, the extravagance of his present giving and public displays of intimacy demonstrate a disregard by both men, and especially Salisbury, for the possible consequences of their actions. Increased policing of London's public spaces had effectively pushed same sex intimacy out of molly houses and parks into more private settings. As Cocks (2010) notes, censorship by the authorities and the secrecy sought by men engaged in same sex intimacy led to a mutually desirable silencing and silence on the subject. Therefore, for the two men to be so openly demonstrative appears at odds with the apparent dangers of their situation. Either they did not care, historical accounts exaggerate the perilousness of the situation for male intimacy or there is another explanation here.

\section{Evidence and Appeal}

What the case does indicate, as Upchurch notes in relation to the Protheoroe $v$ Newberry case, is, 'the power of a charge of unnatural assault to disrupt class relations ${ }^{47}$. At the beginning of September 1827 , Salisbury and Morton visited Oxford and Malvern Wells on a 'botanical tour' to help the older man recuperate from his fall ${ }^{48}$. Morton 'told the magistrates about having Double Bedded rooms at the different Inns where we had an ocation (sic) to stop', suggesting that the men were at least on comfortable terms at the start of the tour ${ }^{49}$. At Malvern Wells, the prosecution claimed, Morton had attempted 'to obtain from Richard anthony (sic) Salisbury the sum of $£ 50$ by threatening to accuse him of an attempt to commit an unnatural 
crime $^{, 50}$. Obviously, Morton denied this, and set about constructing his infirm and elderly former employer as a sexual predator. In both his petition and the deposition to Lord Beecham, Morton re-iterated that Salisbury was previously charged with 'indecent behaviour', to which, 'the prosecutor himself, on cross examination, admitted $^{51}$. He then told the magistrate,

'that my master told me that he had a man some time since who would allow him to spend against his Belly. that Horace and Virgil did the same and that their names lasts (sic) from generation to generation as a measurement of gratitude and respect ${ }^{52}$.

Whether Morton was fabricating the report or not, the reference and justification of same sex intimacy in relation to 'Horace and Virgil' would have suggested that Salisbury, an educated gentleman, had made this or a similar statement. ${ }^{53}$ More importantly, it informed Beecham that one previous charge of indecent behaviour did not fully attest to Salisbury's dissolute lifestyle, and that Salisbury was perhaps in the habit of calling upon his male servants for sexual favours. As King notes, good character was one of the main arguments petitioners' used to appeal for a favourable commutation of their sentence ${ }^{54}$. By questioning Salisbury's character, Morton suggested that his own honesty and account of the alleged assault was more trustworthy, particularly given the nature of the case. Also, by insinuating that he was a serial sodomite, the inference was that Salisbury posed the greater threat to society. This appeal to the moral sensibilities that 'structured much of the discourse of those making and administering the law' was an important component in Morton's petitions, and one that did not necessitate a rigorous examination of the evidence ${ }^{55}$. 
Not that Morton had much choice. He was a poor, unconnected labourer, who a year after his emigration from Ireland had been convicted of extortion. For a man in Morton's class, character had to be proved with references from wealthier and apparently more respectable people. Salisbury was from that wealthier and more respectable class, so his good character was assumed. Therefore, the appeal process and defamation of Salisbury's character was the only strategy open to Morton, who was otherwise condemned to imprisonment on the Leviathan ${ }^{56}$.

But Morton's campaign did not start well. Lord Beecham was suspicious of Morton whilst questioning him at Bow Street. Particularly Beecham was dissatisfied with Morton's explanation of how he acquired such a valuable watch and seals (gifts from Salisbury) and impounded these items 'until they could hear more about the business'. Beecham already knew Salisbury was a gentleman living off his own means, which counted against Morton's re-construction of his former employer as a bad character. Then Morton had let slip that Sir Anthony Carlisle, Extraordinary Surgeon to the Prince Regent (1820-1830), 'used to come now and then to the House', and so added to the magistrate's favourable perception of Salisbury's character and connections $^{57}$.

Additionally, both judiciary and public knew that well placed and wealthy people like Salisbury were targeted by extortionists ${ }^{58}$. In 1779, The Court of the Kings Bench ruled that extortion with the threat of exposure for unnatural acts was robbery, even in the absence of physical violence. The judges argued that threat to reputation in this instance was tantamount to a threat to life ${ }^{59}$. Hence, in 1819 William Peterson and John Andrews were capitally convicted at the Old Bailey of 'a highway robbery, accompanied by a threat to extort money under pretence of charging a man with an abominable crime', though no physical force was used ${ }^{60}$. Convicted at the Old Bailey 
in 1820, both William Arnold and James Tobin were executed for the same offence under similar circumstance ${ }^{61}$. The following year, Castlereagh, the Marquis of Londonderry, allegedly committed suicide rather than face exposure by a man he had had sex with in a brothel near St James's square. In this case, the man had also attempted extortion $^{62}$. By 1827 , the year of Salisbury versus Morton, further recognition of the problem produced statute 6 Geo IV, c.19 whereby 'the extortion of money under threat of exposure for unnatural vices' was recognised in itself and in law as a felony ${ }^{63}$. Thus, despite the pervading legal and social construction of sodomites as unnatural and immoral, the spotlight was also very much on those who sought to gain financially from this situation ${ }^{64}$. Thus, contrary to Morton's expectations, he was most likely viewed with suspicion when, 'anxious to meet the charge, knowing he had done no wrong, went voluntarily to surrender himself up at the Public office in Bow Street ${ }^{65}$.

Unfortunately, Morton's description of the alleged assault cast further doubt on his plea. In his deposition Morton claimed that Salisbury,

Came into my bed and took improper liberties with me... as wanting to fit his legs between mine and putting his tounge (sic) into my mouth. That he my master bought a Bottle of Black tincture and wanted to (lick or ink?) my private parts with it and that he had provenance to make me his adopted heir ${ }^{66}$.

Surely, if this happened at all, Morton must have initially agreed or partially agreed to something. Salisbury was elderly and infirm. He could not have used physical force alone in his attempt to sodomise the twenty-five-year-old labourer. Perhaps Morton, seduced by Salisbury's lavish presents and promise to make him, 'his adopted heir', 
had agreed to share the bed. Perhaps Morton had feared losing his job, 'which he considered more advantageous than labouring as a Gardener' ${ }^{67}$. After all, women subject to employers' advances had agreed to covert sex with male family members, or kept quiet when raped for fear of unemployment and destitution ${ }^{68}$. If this was the case, Morton maintained his silence, and the otherwise sympathetic trial jury rejected his version of events.

Two letters presented at the trial also indicated Morton's guilt. Both were allegedly written by him, and both contained extortionate demands ${ }^{69}$. The first letter 'was found in the prosecutor's pocket' and the other the 'prosecutor's servant stated he had picked up in the area of his master's house'. Predictably, Morton stated that the letters were 'never written nor caused to be written by your petitioner, nor had he any knowledge what so ever of the existence of such Letter (sic) previous to his Trial $^{70}$. To support Morton's claim,

'Two Witnesses attended at the old Bailey on subpoena at the Trial on behalf of Morton to give Evidence as to his Handwriting, but through some mistake his counsel did not call them...these Witnesses, if called would have contradicted Prosecutor to the Letters produced'71.

When the letters were read in court, Morton's counsel 'checked' him to prevent his offer 'to write at the Bar, that the jury might see and compare his Hand-writing with the Letters produced, and no suspicions were aroused regarding the discovery of the letters $^{72}$. Nevertheless, the content of the letters was supported by a witness, George Smith, a grocer from Lambeth. At the trial, Smith testified 'that he over heard (sic) the Conversation as he was passing along the street by accident', during which Morton 
demanded money from Salisbury. Morton denied this, but his unconvincing account of Salisbury's attack, the witness testimony and the letters were enough for the reluctant jury to find him guilty. As he himself admitted,

The respectable jury who tried him according to the Evidence laid before them, could not, perhaps, consistent with a proper discharge of their duty have given a different verdict. ${ }^{73}$

As far as the original verdict is concerned, third party evidence provided by George Smith's testimony appears to have been more decisive than the character and class of either the prosecutor or defendant. Clearly, the presentation of Salisbury as a man who abused wealth and power to realise licentious ends equated with contemporary targets of moral condemnation. By using Salisbury's sexuality and reputation Morton's defence sought to disrupt class relations, and call into question his moral character $^{74}$. In the circumstances, this was the only strategy open to Morton, but it failed because the third party evidence proved too strong. The failure of the original strategy was also reflected in Morton's four month appeal. Whilst the petition, letters and investigations that followed the trial continued to dwell on Salisbury's character and sexuality, the appeal was mainly focused on the soundness of George Smith's testimony.

IV. A Queer Resistance or a 'conspiracy of organised perjuries'?

Like thousands of other petitioners treated in a cursory fashion by the Home Department in the 1820s, John Morton claimed he was innocent. Morton pursued his 
appeal during the four months following his trial. It was largely based upon allegations made by Joseph Lancaster, self-appointed champion of Morton, who was apparently unknown to Morton before his trial ${ }^{75}$. After reading about the case 'in the newspaper', Lancaster wrote to the Home Department claiming that Morton had been the victim of a 'conspiracy of organised perjuries' ${ }^{76}$. The conspiracy, he claimed, was organised by Thomas Ashby, a man of bad character who Lancaster had known 'about 22 years ago in the Stock Exchange'. Ashby had been both wealthy and well connected, but his good fortune ended suddenly after he was indicted upon a capital offence (not stated). According to Lancaster, Ashby only escaped prosecution after 'a Confederate named Edward Smith' gave false testimony under oath. From then on, Ashby had been a swindler, 'and was seven years in the Fleet in some affair of a forged will, or an unnatural case, as I understand he was shunned by all the other prisoners ${ }^{77}$.

In 1826, Joseph Lancaster became Ashby's landlord. During the following year, Ashby approached his landlord to ask 'how he could negociate ( sic), so as to raise money on a Pas. Obit Bond of $£ 1000$ : from a very rich man, a Mr Salisbury, to him'. Suspicious as to how 'so poor a wretch' had come by 'so large an Obligation', Lancaster began to question Ashby ${ }^{78}$. In a remarkable account of his activities, Ashby allegedly told Lancaster 'that this Bond had been given by said Salisbury to him Ashby, as compensation for defeating an Indictment against the said Salisbury for an Offence revolting to Human Nature, ${ }^{79}$. Ashby stated that he made his money by ‘suborning perjuries'. In other words, he arranged for paid witnesses to lie under oath, as Edward Smith had lied on Ashby's behalf twenty-years before. He stated that 'Bill Read the Marlbro (sic) Street Officer' was employed by him to put bills straight before the grand jury, after which 'His Friend Mr Salisbury had come off so well, that 
the Club in St James's street had reballoted him ${ }^{80}$. Morton had complained in his petition that the magistrate had not heard his account before the grand jury examined the bill. He stated quite correctly that,

Had the usual course of bringing the case before a magistrate been pursued, the learned judge, who tried your petitioner, would have had the opportunity of referring to the deposition, and seen your petitioner's answer to the charge ${ }^{81}$

Now it appeared that the manner of obtaining the indictment was not only unusual, as Morton had thought, but a strategy devised by Ashby to exclude Morton from an opportunity to defend himself. Morton's 'friends' had told him that Ashby was 'a sham attorney - a well-known character frequently employed at Tothill Fields and Clerkenwell prison in procuring sham bail' and 'was some years ago connected with a group of swindlers in Thames Street, and was tried at the old Bailey' ${ }^{82}$. After outlining his part in Salisbury versus Morton, Ashby apparently told Lancaster about a number of cases in which he had contrived verdicts through bribery and false testimony. Of particular note was a case involving a man named Archdale, who Salisbury recommended to Ashby. Apparently, Archdale was charged with an offence 'of the same nature' ${ }^{93}$, and Ashby had 'got archdale off',

By sending one of his wretches named Bill Clark, I think, to make an affidavit before a judge or the judges, whereby he had defeated the Marlbro Street Magistrate in their purposed holding to Bail. Adding they attributed it to Harmer. But it was entirely my Own trick, both in devising and considering, 
detailing other minor Circumstances as to the measures in defeating the evidences of the Unfortunate Boy Withers ${ }^{84}$

The wretch sent to give false testimony against him, Morton claimed, was Ashby's associate, George Smith. After the trial, Morton's 'friends' were prevented from questioning Smith about his testimony because he had 'disappeared', and the address he had sworn to at the trial proved to be false. Morton's friends were also 'informed the said Smith is a man of no credit ${ }^{85}$. Ashby too had absconded owing rent, which probably accounted for Lancaster's original interest in Morton's appeal ${ }^{86}$.

Between March and April 1828, Joseph Lancaster wrote five more letters that reiterated or disclosed alleged findings pertaining to Morton's appeal. In March, he claimed that Ashby was the leader of a gang that included George Smith, Bill Clark (from the Archdale case) and 'a woman called Fry'. Smith, Clark and Fry were employed to 'swear peoples (sic) lives away', he wrote, and always gave false addresses to the court ${ }^{87}$. They all worked for or with Adams and Turner, Salisbury's attorneys, and were involved in 'the Foul Conspiracy to Screen Salisbury and $\underline{\text { Sacrifice Morton }}{ }^{88}$. Lancaster's allegations did not prove Morton's innocence, but, if substantiated, they raised serious doubts about the verdict. The jury had strongly recommended mercy and petitioned on behalf of Morton 'on account of the debased character of the prosecutor'. Hence, without the testimony of George Smith and the letters apparently containing Morton's extortionate demand, the jury would almost certainly have found in favour of the defendant. If this had happened, Richard Salisbury would have been charged with attempted sodomy. He could not take that chance. Thus, if Salisbury had hired Ashby's gang, he was probably wise to do so. More importantly, if this was the case, Salisbury appears as other than the passive and 
powerless victim of a heteronormative society and criminal justice system. Salisbury, as a man of means, is the agent of his destiny, who used his wealth to buy back his freedom, and the secrecy that men engaged in same-sex intimacy needed in order to pursue their lives and desires ${ }^{89}$. This, more than anything, is what Morton threatened, and what Salisbury was resisted, using his wealth to do so. Wealth was not an advantage had by the three unsuccessful petitioners referred to earlier, and for that, as well as their offence, they were hanged. That as it may be, Lancaster had done all he could for Morton, and the final decision was in the hands of the Home Department.

\section{Administering to Morton's Appeal}

Perhaps because of the particulars of the case, the possibility of a felony charge or Salisbury's reputation, the Home Department took the unusual step of investigating the claims made by Morton and Lancaster ${ }^{90}$. Denman, the presiding judge, corroborated Morton's claim that the admissibility of the two letters had not been fully tested at the trial. It was even suggested that 'Morton laboured under great disadvantage by having no Solicitor attend in Court at his Trial'. This again suggested unusual sympathy towards Morton, as it was well known that most defendants were too poor to afford counsel. Enquiries concerning the character of Ashby, described as the 'Prosecutor's agent and manager of the Prosecution', found that he was known as a bad character. Two witnesses were also found who could 'prove' that George Smith had given a false address, and had been hired by Ashby to give testimony against Morton $^{91}$. In short, by the end of January 1828 the Home Department had discovered that the evidence for Morton's conviction was uncertain.

Between January and March 1828, the Home Department took further steps to gather evidence pertaining to Morton's conviction. For the first time, a deposition was 
taken from John Morton. Morton took the opportunity to describe in graphic detail Salisbury's alleged assault. To demonstrate that he was not simply retrospectively inventing a charge against Salisbury to exonerate himself, Morton deposed that he had reported the assault to a Worcester Magistrate following advice from James Harmer. To corroborate this, Under Secretary of State, JM Phillipps, wrote to Reverend Bentley of Worcester asking if he remembered Morton laying 'a charge before you against a person of the name of Salisbury, and in the event of you recollecting such a circumstance, that you will state the nature of the charge ${ }^{, 92}$. No reply was received. James Harmer was also asked about his consultation with Morton. Harmer remembered the meeting, but had refused to help Morton because he suspected he was trying to extort money from Salisbury ${ }^{93}$. This was not a good start to the investigation for Morton.

In March, four more depositions were sworn before Robert Birnie at Bow Street, and forwarded to the Home Department. Ann Morton, who had thus far been silent, deposed that she had been in Queen Street when George Smith allegedly overheard her husband's extortionate demands. George Smith was not present, she stated, and no such demands had been made, but 'a slight altercation took place between them about the clothes which Salisbury had made Morton a present of upon entering his Service'. However, Ann's deposition was rendered worthless by Robert Birnie, who wrote at the end that, 'I do not think the affidavit of a wife should be taken' ${ }^{94}$. Depositions given six days later by Morton's 'friends', attesting to George Smith's bad character, false testimony and the bogus address given under oath, were also viewed as partial, and contributed nothing to Morton's appeal ${ }^{95}$. In fact, by the beginning of April 1828, Morton's appeal was all but over. The damage done by Bentley's unexplained silence and Harmer's professional outrage had not been 
rectified, and the Home Department had been unable to corroborate Lancaster's allegations. To add to this, Lancaster's letters began arriving from the King's Bench Prison, where he had been incarcerated for debt and assault at the behest of Thomas Ashby. Predictably, Lancaster claimed the charges had been manufactured, but his incarceration undermined both his character and the claims made regarding Morton's prosecution. At this point, the Home Department terminated the investigation, and Morton's appeal ended ${ }^{96}$.

\section{Conclusion}

One case cannot provide us with a template by which to understand all contemporaneous experiences of same sex intimacy between men. Yet, an interrogation of the Morton versus Salisbury case does suggest a number of conclusions. First, narrow and deterministic structural explanations of responses to and experiences of men seeking intimacy with other men in the early nineteenthcentury do not stand up to scrutiny. Whilst negative constructions of sodomites circumscribed this case, there was never any suggestion that Salisbury's prosecution should fail or the jury dismiss evidence against Morton because the prosecutor had previously been charged with indecent assault. Morton was indicted and prosecuted on the evidence presented at his trial. Of course, Salisbury and Ashby may well have concocted this evidence, but Salisbury faced a charge of attempted sodomy if Morton was found innocent. Given that the legal construction of sodomy had made the alleged offence possible, Salisbury cannot be blamed if he paid to protect himself from the prejudices of the courts. In fact, as Cocks argued, the trial was about supressing information about the alleged intimacy to protect Salisbury's privacy and his life. In this, the aims of both Salisbury and the Judiciary were symbiotic. 
However, contemporary constructions of sodomy only partially explain the outcomes of this case. Clearly, Salisbury was a wealthy man. He was able to soft-soap Morton with gifts, and take him into exclusive social situations. His demonstrable wealth may even have encouraged Morton to attempt extortion. But Salisbury's wealth and privilege also made it possible for him to exploit Morton's naivety, poverty and inability to afford legal representation. Wealth made Salisbury vulnerable to extortion, but it also provided the means to secure Morton's conviction. Thus, the case, the prosecution of the trial and verdict were also contingent upon class power and privilege.

The intersection of class and heteronormative constructions of sexuality almost certainly influenced the orientation of Morton's appeal. Viewed in this way Morton's allegation of attempted sodomy against a man previously charged for similar offences may suggest one motive for the Home Department's investigation. However, it seems more plausible to suggest that the investigation was primarily concerned with Lancaster's allegations of fake witnesses and false evidence. That the investigation ceased once Lancaster was disregarded as credible also lends credence to this argument. If the investigation had been initiated solely or mainly on the basis of Salisbury's reputation, it would have continued despite Lancaster's indisposition. So, in the end justice was most likely served, but not without detriment to Salisbury's purse, reputation and the final year of his life.

\footnotetext{
${ }^{1}$ Many thanks to Dr Jane Attfield, Dr Martin O’Brien, Dr Robert Poole and Dr Chris Williams for their suggestions and encouragement during the writing of this article. Thank you also to the editorial team and anonymous referees at History: The Journal of the Historical Association for their invaluable comments and support.

${ }^{2}$ Richard Anthony Salisbury is best known for, The Genera of Plants (London: J Van Voorst, 1866) published posthumously, and still available in print. Royal Horticultural Society www.rhs.org.uk (accessed 08/09/09); DE Allen, 'Salisbury [Formerly Markham] Richard Anthony (1761-1829)' in Dictionary of National Biographies (ODNB) 2004
} 
${ }^{3}$ HO17/16: 'Petition of Ann Morton on behalf of John Morton to Mr Goulbourn, $31^{\text {st }}$ March 1829: Ann Morton is hardly mentioned during the trial or during the appeal.

${ }^{4}$ OBSP (Old Bailey Session Papers): 1827, $1^{\text {st }}$ session, $6^{\text {th }}$ and $7^{\text {th }}$ December (Case 68); HO17/16: 'Petition of John Morton to the Marquis of Lansdowne', 24 ${ }^{\text {th }}$ December 18271

${ }^{5}$ C. Upchurch, Before Wilde: Sex between Men in Britain's Age of Reform (Berkeley, Los Angeles and London, 2013), p. 2.

${ }^{6}$ Upchurch, Before Wilde, p. 50.

${ }^{7}$ H.G. Cocks, Nameless Offences: Homosexual Desire in the Nineteenth-century (London and New York, 2010), p. 20-21.

${ }^{8}$ Cocks, Nameless Offences, p. 77; H.G. Cocks, 'Making the Sodomite Speak: Voices of the Accused in English Sodomy Trials, c.1800-98’, Gender and History, 18/1 (2006), pp. 87-107, at p. 91.

${ }^{9}$ Cocks, Nameless Offences, p. 21.

${ }^{10}$ Upchurch, Before Wilde, p. 63-64.

${ }^{11}$ Upchurch, Before Wilde, p. 8-9; R. Trumbach, Sex and the Gender Revolution: Volume I, Heterosexuality and the Third Gender in Enlightenment (Chicago and London, 1998), pp. 55-63.

${ }^{12}$ M. Brown 'Gender and Sexuality 1: Intersectional anxieties', Progress in Human Geography, 36/4 (2012), 541-550 at p. 542; For a fuller discussion of these issues, see H. Abelove, M.A. Barale and D. M. Halperin (eds), The Lesbian and Gay Studies Reader (London, 1993).

${ }^{13}$ Cocks, Nameless Offences, p. 4

${ }^{14}$ L Marhoefer, 'Lesbianism, Transvestitism, and the Nazi State: A Microhistory of Gestapo Investigation, 1929-1945', American Historical Review, 121/6 (2016), pp. 1167-1195, at p. 1172.

${ }^{15}$ Old Bailey Sessions Papers [hereafter OBSP], $1^{\text {st }}$ session, $6^{\text {th }}$ and $7^{\text {th }}$ December 1827 , Case 68.

16 The National Archive [hereafter TNA], HO17/16, Petition of John Morton to the Marquis of Lansdowne, $24^{\text {th }}$ December 1827.

${ }^{17}$ OBSP, December 1827.

${ }^{18}$ Ibid.

${ }^{19}$ TNA, HO17/16, Deposition of John Morton, January 1828.

${ }^{20}$ Upchurch, Before Wilde, p. 63.

${ }^{21}$ OBSP, December 1827.

22 TNA, HO17/16, Deposition of Mr Harmer, January 1828.

${ }^{23}$ Ibid.

${ }^{24}$ TNA, HO17/16, Petition of John Morton, 24 ${ }^{\text {th }}$ December 1827.

${ }^{25}$ Trumbach, Sex and the Gender Revolution, pp. 5-22.

${ }^{26}$ Selectively, N. Murray Goldsmith, The Worst of Crimes: Homosexuality and the Law in Eighteenth Century London (Aldershot, 1998). Ian McCormick, Secret Sexualities: A Sourcebook of $17^{\text {th }}$ and $18^{\text {th }}$ Century Writing (Oxon and New York, 1997), p. 69, argues that contemporary juries were unwilling to 
return guilty verdicts in cases of sodomy, and follows Paley's criticism that juries were unwilling to return guilty verdicts in capital cases generally. For a full discussion of contemporary arguments around the mitigating role of juries in the eighteenth century see K.J.M. Smith, Lawyers, Legislators and Theorists: Developments in English Criminal Jurisprudence 1800-1957 (Oxford, 1984) and P. King, 'Decision Makers and Decision Making in the English Criminal Law 1750-1800', The Historical Journal, 27/1 (1984), pp. 25-58.

${ }^{27}$ H. Cocks, 'Calamus in Bolton: Spirituality and Homosexual Desire in Late Victorian Society', Gender and History, 13/2, (2001) pp. 191-223, states that more systematic punishments were applied to same-sex relationships (amongst men) after 1780. Certainly, changes in punishment and legal responses were evident in the aftermath of the American war; Also, see A.D. Harvey, 'Prosecutions for Sodomy in England at the Beginning of the Nineteenth Century', The Historical Journal, 21/4 (1978), pp. 939-948; T. Hitchcock, English Sexualities 1700-1800 (Basingstoke and London, 1997), pp. 58-75; Alan Bray, Homosexuality in Renaissance England (London, 1982), pp. 81-114; R. Trumbach, Journal of Social History, 11/1 (1977), pp. 1-33, at pp. 15-22, for discussion of the prosecution of mollies in the eighteenth century and indictments for sodomy in the 1790's.

${ }^{28}$ L. Crompton, Homosexuality and Civilisation (Harvard, 2003), p. 529.

${ }^{29} \mathrm{Ibid}$, pp. 530 \& 532. In fact, Crompton edited the first publication of Bentham's essay in the Journal of Homosexuality, $3 / 4$ (1978), pp. 389-405.

${ }^{30}$ Appendix III, from Parliamentary Papers, 1819, XVII, reproduced in A.D. Harvey, Prosecutions for Sodomy, pp. 939-948, provides figures for committals and executions up to and including 1818; Sodomy was not the only capital offence for which committals and convictions rose during this period, but, as Gatrell notes, rising committals and convictions were more usually a feature of property crimes V.A.C. Gatrell, The Hanging Tree: Execution and the English People 1770-1868 (Oxford, 1996), pp. 19-20.

${ }^{31}$ I. Bloch, Sexual Life in England, Past and Present (London, 1938), pp. 414.

32 D.E. Allen, 'Salisbury [formerly Markham], Richard Anthony (1761-1829), botanist and horticulturist' Oxford Dictionary of National Biography (2004), http://www.oxforddnb.com/view/10.1093/ref:odnb/9780198614128.001.0001/odnb-9780198614128-e24542.

33 The Morning Chronicle, 10th July 1810, in Rictor Norton (ed.), "The Vere Street Club, 1810", Homosexuality in Nineteenth-Century England: A Sourcebook, 7 May 2008, updated 7 September 2008 http://rictornorton.co.uk/eighteen/1810vere.htm

${ }^{34}$ POLICE, BOW STREET, July $10^{\text {th }} 1810$, in Rictor Norton (ed.), "The Vere Street Club, 1810", Homosexuality in Nineteenth-Century England: A Sourcebook, 7 May 2008, updated 7 September 2008 http://rictornorton.co.uk/eighteen/1810vere.htm

35 Jackson's Oxford Journal, Issue 2996, in Rictor Norton (ed.), "The Vere Street Club, 1810", Homosexuality in Nineteenth-Century England: A Sourcebook, 7 May 2008, updated 7 September 2008 http://rictornorton.co.uk/eighteen/1810vere.htm

${ }^{36}$ The Times, $28^{\text {th }}$ September 1810, 'The Pillorying of the Vere Street Club', reproduced in C. White, Nineteenth-Century Writings on Homosexuality: A Sourcebook (London and New York, 1999), p. 11. This report includes details of four other men, convicted of 'similar crimes', who were attacked by a crowd (using sticks and stones) whilst being transported to Cold Bath Fields prison. Also, see Bloch, Sexual Life in England, pp. 403-412.

${ }^{37}$ TNA, HO17/16, Juror's petition on behalf of John Morton, 24 ${ }^{\text {th }}$ March 1828.

${ }^{38}$ This case bears remarkable similarities to the Protheroe $v$ Newbury case, cited in Charles Upchurch, Before Wilde: Sex Between Men in Britain's Age of Reform (Berkeley, Los Angeles and London: University of California Press, 2013) 77-78 
${ }^{39}$ VAC Gatrell, The Hanging Tree, 198

${ }^{40}$ TNA, HO 6/7, List of Capital Convicts to be Reported to His Majesty in Council the $22^{\text {nd }}$ Day of November 1822

${ }^{41}$ Ibid.

${ }^{42}$ TNA, HO 6/13, List of Capital, 22 ${ }^{\text {nd }}$ Day of November 1822.

43 TNA,HO17/30/Dm 10.

${ }^{44}$ Ibid.

${ }^{45}$ Similarly, those supporting John Noden's appeal against a conviction for the rape suggested that Elizabeth Cureton's alleged bad character and promiscuity be considered as mitigation for Noden's attack upon her. See V.A.C. Gatrell, The Hanging Tree, pp. 447-493.

${ }^{46}$ William Oldnall Russell, A Treatise on Crimes and Misdemeanours, Vol. 1 (London, 1819), pp. 816.

${ }^{47}$ Upchurch, Before Wilde, p. 78.

${ }^{48}$ OBSP: $1827,1^{\text {st }}$ Session, $6^{\text {th }}$ and $7^{\text {th }}$ December (Case 68$)$.

49 TNA, HO17/16, Deposition of John Morton, January 1828.

${ }^{50}$ TNA, HO17/16, Petition of John Morton', 24 ${ }^{\text {th }}$ December 1827.

${ }^{51}$ Ibid.

52 TNA, HO17/16, Deposition of John Morton, January 1828.

${ }^{53}$ Trumbach Sex and the Gender Revolution, pp. 73-90, demonstrates that for over than a century wealthy libertines had justified or explained various sexual practises, including sodomy, with reference to the writings and philosophies of antiquity. This point is supported by Upchurch, Before Wilde: p. 51.

${ }^{54}$ P. King, Crime, Justice and Discretion in England, 1740-1820 (Oxford, 2000), chapter 8.

${ }^{55}$ M. Wiener, Reconstructing the Criminal: Culture, Law and Policy in England 1830-1914 (Cambridge, 1990), p. 53.

56 The Leviathan was a prison hulk anchored at Portsmouth, England.

57 TNA, HO17/16, Deposition of John Morton, January 1828. W. Bynum, 'Carlisle, Sir Anthony (1768-1840), surgeon and anatomist', Oxford Dictionary of National Biography (2004), http://www.oxforddnb.com/view/10.1093/ref:odnb/9780198614128.001.0001/odnb-9780198614128-e4687, states that Sir Anthony Carlisle [1768-1840] was a Founder of the Royal College of Surgeons (1804) and fellow of the Royal Society. He is credited with the discovery of electrolysis (1800), and propounded the view that bodies could be revived with electricity. He shared Salisbury's interest in botany, and listed amongst Carlisle's publications is a letter to Salisbury (1916) in which he includes his paper 'On the Connection Between the Leaves of Fruit and Vegetables; With Other Physiological Observations'.

${ }^{58}$ Oldnall Russell's review of blackmail cases involving threats to expose men for 'sodomitical practises' refers to a landmark case from 1779, Wm. Oldnall Russell, A Treatise on Crimes and Misdemeanours, 2 Vols., (Boston, 1824), Volume II, pp. 1008-1024 in Rictor Norton (ed.),

Homosexuality in Nineteenth-Century England: A Sourcebook, 7 May 2008, updated 7 September 2008 http://rictornorton.co.uk/eighteen/1810vere.htm; See also Trumbach, Sex and the Gender Revolution, pp. 55-58 for similar cases from the eighteenth-century.

59 Ibid. 
${ }^{60}$ Morning Post, $22^{\text {nd }}$ November 1819 , in Rictor Norton (ed.), Homosexuality in Nineteenth-Century England: A Sourcebook, 7 May 2008, updated 7 September 2008 http://rictornorton.co.uk/eighteen/1810vere.htm;

${ }^{61}$ Hereford Journal, $12^{\text {th }}$ July 1820 and Glasgow Herald, $5^{\text {th }}$ February 1821 in Rictor Norton (ed.), Homosexuality in Nineteenth-Century England: A Sourcebook, 7 May 2008, updated 7 September 2008 http://rictornorton.co.uk/eighteen/1810vere.htm;

62 'The Fall of the Marquees of Londonderry, 1822, Revd John Richardson, from recollections, Political, Literary, Dramatic, and Miscellaneous, of the Last Half-Century (1855)', reproduced in C. White (ed.) Nineteenth Century Writings on Homosexuality, pp. 31-32.

${ }^{63}$ A.D. Harvey, Prosecutions for Sodomy, pp. 943.

${ }^{64}$ Upchurch, Before Wilde, pp. 63-4.

65 TNA, HO17/16, Petition of John Morton, 24 $4^{\text {th }}$ December 1827.

66 TNA, HO17/16, Deposition of John Morton, January 1828.

${ }^{67}$ TNA, HO17/16, Petition of John Morton, $24^{\text {th }}$ December 1827.

${ }^{68}$ Francoise Barret-Ducrocq, Love in the Time of Victoria: Sexuality and Desire Among Working-Class Men and Women in Nineteenth-Century London (Harmondsworth, 1989/1991), pp. 66-73. The cases discussed by Barret-Ducrocq came into the public domain when poor and pregnant women appealed to the Foundling Hospital, London, to care for their child. Without these circumstances, such cases remained hidden from history, as, no doubt, did assaults by male employers on male staff that did not involve a criminal prosecution.

${ }^{69}$ OBSP, $1827,1^{\text {st }}$ Session, $6^{\text {th }}$ and $7^{\text {th }}$ December (Case 68).

70 TNA, HO17/16, Petition of John Morton, 24 ${ }^{\text {th }}$ December 1827.

${ }^{71}$ TNA, HO17/16, Unsigned, 'Additional Facts relative to the Case of John Morton', 29 $9^{\text {th }}$ January 1828.

72 Ibid.

73 TNA, HO17/16, Petition of John Morton, 24 ${ }^{\text {th }}$ December 1827.

${ }^{74}$ Upchurch, Before Wilde, pp. 61.

${ }^{75}$ G. Bartle, 'Lancaster, Joseph (1778-1838), educationist'. Oxford Dictionary of National Biography (2004), http://www.oxforddnb.com/view/10.1093/ref:odnb/9780198614128.001.0001/odnb9780198614128-e-15963 This was not Joseph Lancaster, the educationalist. He was in Venezuela or the West Indies at the time these letters were written, and had been in North America for some time before.

${ }^{76}$ TNA, HO17/16, Letter from Joseph Lancaster to the Secretary of State for the Home Department, $23^{\text {rd }}$ January 1828.

77 TNA, HO17/16, Letter from Joseph Lancaster, King's Bench Prison, to the Capper Esq., Superintendent of Hulks, $8^{\text {th }}$ April 1828.

78 TNA, HO17/16, Letter from Joseph Lancaster to the Secretary of State for the Home Department, $23^{\text {rd }}$ January 1828.

${ }^{79}$ TNA, HO17/16, Affidavit from Joseph Lancaster, King’s Bench Prison, April 1828. 
${ }^{80}$ TNA, HO17/16, Letter from Joseph Lancaster to the Secretary of State for the Home Department, $23^{\text {rd }}$ January 1828.

${ }^{81}$ TNA, HO17/16, Petition of John Morton, 24 ${ }^{\text {th }}$ December 1827.

${ }^{82}$ Ibid.

${ }^{83}$ TNA, HO17/16, Affidavit from Joseph Lancaster, King’s Bench Prison, April 1828.

${ }^{84}$ TNA, HO17/16, Letter from Joseph Lancaster to the Secretary of State for the Home Department, $23^{\text {rd }}$ January 1828.

${ }^{85}$ TNA, HO17/16, Petition of John Morton, 24 ${ }^{\text {th }}$ December 1827.

${ }^{86}$ TNA, HO17/16, Letter from Joseph Lancaster to the Secretary of State for the Home Department, $23^{\text {rd }}$ January 1828.

${ }^{87}$ TNA, HO17/16, Letter from Joseph Lancaster to Capper, Superintendent of the Hulks', $6^{\text {th }}$ March 1828.

${ }^{88}$ TNA, HO17/16, Letter from Joseph Lancaster to Capper, Superintendent of the Hulks', $20^{\text {th }}$ March 1828.

${ }^{89}$ H.G. Cocks, Nameless Offences, pp. 4-5

${ }^{90}$ See Rosemary Pattenden, English Criminal Appeals 1844-1944 (Oxford, 1996), pp. 19

${ }^{91}$ TNA, HO17/16, Unsigned, 'Additional Facts relative to the Case of John Morton', 29 't $^{\text {th }}$ anuary 1828.

${ }^{92}$ TNA, HO17/16, Letter from JM Phillipps, Whitehall, to Rev'd Mr Bentley, Worcester', 22 ${ }^{\text {nd }}$ January 1828.

93 TNA, HO17/16, Deposition of Mr Harmer, January 1828.

94 TNA, HO17/16, Deposition of Ann Morton Wife of John Morton, 25 ${ }^{\text {th }}$ March 1828.

95 TNA, HO17/16, Deposition of Benjamin William Caston, Cabinet Maker, $31^{\text {st }}$ March 1828; TNA, HO17/16, Deposition of Edward Chamberlain, Painter, $31^{\text {st }}$ March 1828; TNA, HO17/16, Deposition of Edward Butler, Undertaker, $31^{\text {st }}$ March 1828.

96 TNA, HO17/16, Affidavit from Joseph Lancaster, King's Bench Prison, April 1828. 